Article

\title{
Dismissals and Temporary Leaves in Romanian Companies in the Context of Low Demand and Cash Flow Problems during the COVID-19 Economic Lockdown
}

\author{
Elena-Sabina Turnea ${ }^{1, *}\left(\mathbb{D}\right.$, Ștefan Andrei Neștian ${ }^{1}\left(\mathbb{D}\right.$, Silviu Mihail Tiță ${ }^{1}\left(\mathbb{D}\right.$, Ana Iolanda Vodă ${ }^{2} \mathbb{D}$ \\ and Alexandra Luciana Guță ${ }^{1}$ (D) \\ 1 Department of Management, Marketing and Business Administration, \\ Alexandru Ioan Cuza University of Iași, Blvd. Carol I, No. 22, 700505 Iași, Romania; \\ nestian@uaic.ro (S.A.N.); silviutita@yahoo.com (S.M.T.); luciana_guta@yahoo.com (A.L.G.) \\ 2 Social Sciences and Humanities Research Department, Institute for Interdisciplinary Research, Alexandru \\ Ioan Cuza University of Iasi, Lascăr Catargi Street, No. 54, 700107 Iaşi, Romania; yolanda.voda@gmail.com \\ * Correspondence: sabina.turnea@uaic.ro or sabina.turnea@yahoo.com; Tel.: +40-744-951-559
}

Received: 15 September 2020; Accepted: 23 October 2020; Published: 25 October 2020

check for updates

\begin{abstract}
The aim of this study is to describe the relations between low demand, cash flow problems, employee dismissals, and temporary leaves experienced by Romanian companies during the economic lockdown in the first two months of the COVID-19 pandemic outbreak in Romania (16 March-16 May 2020). For this purpose, we conducted a quantitative study using descriptive, correlation, and regression analyses applied to data collected from company decision-makers. Our results show that demand for products/services and cash flow in companies has decreased significantly, the workforce being affected by dismissals and temporary leaves/furloughing. Additionally, the average linear revenue of companies has been decreasing due to insufficient cash flow, higher absenteeism of workers, customers having been affected, and the demand going down. Therefore, employee dismissals, employee temporary leaves (furlough), and dismissal intentions have been positively correlated with insufficient cash flow in companies and an extremely low demand.
\end{abstract}

Keywords: COVID-19; pandemic; companies; dismissal; temporary leave; cash flow; low demand; Romania; furlough; challenges

\section{Introduction}

The year 2020 will definitely remain in history as the year of both SARS-CoV-2 pandemic and the year of great economic lockdown. This pandemic has been seen as one of the determinants of current global economic changes [1]. In this general context, the study investigates the economic impact of this pandemic in Romania. The financial crisis of 2007-2008 generated a severe contraction of liquidity on international markets [2]. Similarly, the effect of SARS-CoV-2 pandemic resulted in low demand and cash flow problems in companies, affecting the condition of human resources [1]. From this perspective, the study aims to describe the main challenges faced by Romanian companies during the first two months of the pandemic outbreak in Romania (16 March-16 May 2020) in order to gain a better understanding of particularities of the current economic crisis by focusing mainly on the relations between low demand, cash flow problems and employee dismissals and temporary leaves. For this purpose, we carried out a quantitative study by using descriptive, correlation, and regression analyses, data having been collected from company decision-makers (managers, shareholders, company owners, administrators, etc.) during the state of emergency that had been established in Romania after the 
outbreak of COVID-19. So, we have formulated and tested six hypotheses describing the relations between low demand, cash flow problems, and employee dismissals and temporary leaves.

This study seeks to answer the following research question: What are the relations between low demand, cash flow problems, dismissals, and temporary leaves of employees generated by the lockdown that had been imposed by the Romanian Government during the first two months of the COVID-19 pandemic? For this purpose, we conducted a survey in more than 200 Romanian companies using a questionnaire that had been translated and adapted from the International Labour Organization (ILO) [3]. Data were collected between 1-16 May 2020 from managers of Romanian companies, providing full confidentiality of responses.

The general context of this study is the global spread of the SARS-CoV-2 virus. The first human cases of COVID-19, the coronavirus disease caused by SARS-CoV-2, were first reported in China, back in December 2019 in the city of Wuhan. [4]. In December 2019, the Chinese authorities made a preliminary determination of a new coronavirus, identified in a hospitalised patient with pneumonia in Wuhan [5]. On 11 March 2020, the World Health Organization (WHO) issued a statement on the pandemic nature of the COVID-19 outbreak. At that time, almost 125,000 cases had been reported to $\mathrm{WHO}$, covering 118 countries. Two weeks before the announcement of the pandemic, the number of cases outside China had grown almost 13-fold, while the number of affected countries almost tripled [6]. The COVID-19 pandemic affected all areas of life in countries experiencing epidemic outbreaks. To prevent further increase of the cases, countries applied a wide range of preventive measures with such direct effects on the economy as closure of schools and markets, cancellation of flights and other forms of travel or tourism, and prohibition to hold public events, etc. [1,7,8].

In Romania, the National Centre for Surveillance and Control of Communicable Diseases stated that until 18 March 2020, 261 cases of COVID 19 coronavirus infection had been confirmed. The first case of confirmed infection was recorded on 26 February 2020, with 1-2 daily cases having been confirmed in the following 12 days. Starting with 10 March, the upward trend has accelerated to an approximate average of 30 cases per day. The virus was brought to the country by people returning from European countries, 127 of the 261 new cases having been recorded in persons returning to Romania from abroad. The share of imported cases reached $49 \%$ on 18 March, a decrease compared to the first days of the epidemic in Romania, when the percentage reached $100 \%$. The infected persons were returning to Romania from Italy (66\%), France, Germany, and Spain (5\%), and the United Kingdom and Austria (4\%) [9]. Due to the high incidence of the coronavirus cases, on 16 March 2020, the President of Romania issued a decree establishing the state of emergency in Romania [7]. One month later, it was extended by one more month [10]. So, Romania had been from 16 March to 16 May 2020 under a state of emergency due to the pandemic. The measures with an immediate economic impact included: Isolation and quarantine of people arriving from risk areas, closure of state borders, restriction of movement of people and vehicles, prohibition of road, rail, sea, river, or air traffic, and temporary closure of restaurants, cafes, and clubs [9].

Many economic activities were directly affected by the newly imposed restrictions. Food serving and consumption of alcoholic and non-alcoholic beverages in restaurants, hotels, cafes, or other public places was prohibited, except for the drive-ins, room-services, or customer delivery. Additionally, all cultural, scientific, artistic, religious, sporting, entertainment or gambling, spa treatments, and personal care activities carried out indoors were cancelled, as well as any event attended by more than 100 people and several flights. People isolated in their homes, were quarantined, or hospitalised as measures taken to prevent the spread of COVID-19 without the approval of competent authorities [11]. Medical services were also affected, the activity of dental clinics being temporarily stopped. Retail sale of products and services in shopping malls was also temporarily suspended, except for the sale of food, veterinary or pharmaceutical products, and provision of cleaning services [12].

The restrictions imposed on free movement of people had also indirectly affected the demand, especially for services. Movement of all people outside their homes was allowed only for precisely defined and proven reasons: Professional purposes, basic needs, medical care, short trips, blood 
donation, agricultural activities, and other justified reasons, such as childcare or assistance for the elderly and the sick [13]. The elderly, aged over 65, being one of the most vulnerable categories, were most affected by the restrictions. They had to stay indoors to protect themselves, having been allowed to leave the house only between 11:00 a.m. and 1:00 p.m. [13]. All these restrictions had a significant impact on consumer behaviour, leading to changes in demand and, consequently, poor operation of all businesses in terms of their revenue, cash flow, and financial standing. Home delivery services saw an increase in demand, while conventional shops, isolated or placed in shopping malls, stopped or reduced their operations. Work from home turned out to be an efficient solution for social distancing, leading, in the end, to less fuel consumption and lower demand for several work-related items (e.g., clothes, perfumes, and fashion accessories), or products usually consumed at work (e.g., biscuits, soft drinks, sandwiches). Low demand had observable consequences in terms of unemployment, reduced working time, or employee furloughing. Due to these restrictions, until 17 May, Romania recorded only 16895 COVID cases compared to its population of around 19 million inhabitants (less than $0.09 \%$ ), $76.6 \%$ of deaths having been among people aged over 60 , and in $90.5 \%$ of the deaths due to, at least, one associated comorbidity [14].

During this period, Romania managed successfully to prevent the spread of the epidemic, although at high economic cost.

The study was divided into following sections: The literature review section outlines the latest developments in the field; the methodology section describes the used research methods; the last part of the study discusses the results and the conclusions.

\section{Literature Review}

The labour market has been undoubtedly affected by the SARS-CoV-2 pandemic. COVID-19 crisis led to changes in such work arrangements as: Flexible location, flexible working hours, financial changes, shorter schedule, etc. [15]. Data on the US labour market shows a dramatic rise in unemployment insurance claims, and growth in underemployment and unemployment rates [16]. A study conducted in China with 369 participants, $25 \%$ of respondents, who stopped working due to the outbreak, reported worse mental and physical health conditions, as well as distress [17]. In India, job dismissals and cuts in wages were expected by employees during COVID-19, especially in malls, restaurants, tourism, airlines, retailers, and the film industry [18]. The argument for workforce cuts seems to be similar all over the world: Enterprises are not able to generate profit $[18,19]$.

It is unclear what will happen to employees with flexible employment relationships, as in the case of temporary agency work and other forms of subcontracted labour, where employees are not officially laid off, or on paid sick leave [15]. In such cases, employees may remain unprotected [15]. In the Ukrainian Labour Code, there are no provisions regarding the right of the employer to dismiss employees during quarantine, and it is forbidden to adopt any additional laws to regulate dismissals as a measure for counteracting the spread of COVID-19 [20]. In Romania, employers have the right to dismiss employees if the economic situation of a company asks for it, but they cannot discharge a person being on quarantine leave [21]. However, governments started providing economic support for affected enterprises through tax cuts, rent reductions, wage subsidies, and even cash transfers [22].

Like everyone, we have no answers and share the global uncertainty on how normality is going to look like on the labour market when all comes back to normal $[23,24]$. Still, the response of companies should follow two main objectives: A quick redistribution of employees to urgent activities and taking actions that maintain employee attachment $[25,26]$. Additionally, employers and employees should act in good faith in order to obtain a smart recovery of working arrangements [27]. Before any dismissal, employers should provide to employees enough information justifying the dismissal decision, and let them comment on the option [27]. At the core of managerial work is the decision-making process [28], and this process may be viewed as a moderating factor between organizational performance and sustainability [29]. Even more, in pandemic times, inspired and well-grounded decisions become vital. 
In our study, managers were asked if they dismissed or intended to lay off employees due to COVID-19 crisis, and, if so, they had to tick the percentage of dismissed employees. As a result, at least theoretically, the two variables should be correlated, showing that the respondents were in good faith and answered honestly the two questions, which is an important factor for our analysis. Therefore, the first hypothesis has been formulated:

Hypothesis 1. There is a positive correlation between the act of dismissing employees/the intention to dismiss employees due to the crisis caused by COVID-19 and the percentage of dismissed employees (calculated as a percentage out of total workforce).

The consequences of COVID-19 epidemic are severe and visible, especially in what regards the labour force, in the rate of unemployment [1,30-34]. In the Organisation for Economic Co-operation and Development (OECD) countries, the unemployment rate rose to 8.4\% in April 2020 compared to 5.5 in March 2020 [35]. In the United States, 26.5 million people were fired, the equivalent of over $20 \%$ in unemployment [36]. Still, the U.S. Bureau of Labour Statistics reported in June 2020 that the unemployment rate decreased, since efforts had been made to resume economic activities [37]. A survey conducted by ILO Score Programme indicated that many companies have implemented drastic changes since the start of COVID-19, such as: Unpaid leaves, reduced wages by $20 \%$, even laying off staff [1].

The main impact of COVID-19 in small and medium-sized enterprises (SMEs) can be seen in supply chain disruption, cash flow imbalance, and risk of bankruptcy [22,30,38]. An online survey applied to Malaysian SMEs reported that cash flow had been severely affected, companies having difficulties in paying staff wages, rent, or making other payments [30]. The Indian economy has also become vulnerable, since the cash flow has been significantly reduced [18]. A limited cash flow was also found in SMEs in Canadian food processors [39]. Even if restaurants, as well as shops, are slowly opening and many of them cannot afford to pay even their rent [40], it is obvious that liquidity is now the main problem in companies.

Due to the economic crisis, employers were no longer able to pay wages, and thus, employees lost their jobs [41]. However, there are several options for organizations interested in keeping a balance between maintaining personnel and a level of cash flow in business: Reduction of high salaries, paid leaves, sabbatical periods; reduction of working hours; temporary payroll cuts [42]. The most severe option is dismissal of employees, which is a forced decision taken when a business needs to survive [42]. Companies should protect their employees and develop treasury plans for cash flow to ensure continuity of their activities [43-45]. Foresight business operations should also be seen as an important action by managers [30], and companies which have not been affected yet by COVID-19 should also prepare scenarios and plan their cash flow [43].

In our study, managers were asked if they dismissed or intended to dismiss employees due to COVID-19 crisis. They were also asked to disclose whether the cash flow of their companies had been insufficient. Considering all the arguments presented above for connecting dismissals with low liquidity in companies, the second hypothesis has been formulated:

Hypothesis 2. There is a positive correlation between the dismissal of employees/the intention to dismiss employees due to the crisis generated by COVID-19 and the fact that the cash flow for maintaining staff and company's actions is insufficient.

A slightly different perspective appears if we consider the type of dismissals, which can be permanent or temporary. In our research, managers were also asked what had been the percentage of laid off employees, taken as a temporary measure, due to the COVID crisis. Taking into consideration all previous arguments, including those used to formulate $\mathrm{H} 2$, the following hypothesis has been formulated: 
Hypothesis 3. There is a positive correlation between the percentage of employee layoffs due to the crisis generated by COVID-19 and the fact that the cash flow for maintaining staff and the company's actions are insufficient.

Consumer demand has been affected in retail companies in the context of the COVID-19 crisis [38]. Consumption and purchasing behaviours have changed lately, and online shopping has become rather usual [34]. In Africa, sales went down during the pandemic, and two out of three companies stated having been seriously affected [46]. In Romania, the fashion industry and luxury retailers, as well as vendors, have been deeply affected [47]. In Spain, in the city of Santander, the demand for public transport decreased by $93 \%$ [48]. A study in UK found that $65 \%$ of companies reported that their turnover had been lower than normal [49]. International mobility restrictions have negatively affected tourism operations, and the associated food services and handcrafts [50,51]. Unfortunately, there are irrecoverable financial losses in tourism, with severe implications seen in unemployment [52]. The demand for products and services has been globally affected [53,54], with small companies being the most affected [55].

This pandemic has brought wake up signals for businesses [22,56]. Companies have changed the levels of their operations due to lower demand, and these disruptions have led to unemployment and lower income levels $[34,38,57]$. Since employment was severely affected, companies and governments should be prepared and take measures as soon as possible [58]. We believe there are several measures that could counteract low demand and balance the unemployment rate, first being the furloughing, a temporary reduction in hours or weeks of work. Employees still have a job and remain on the payroll, but they become eligible for unemployment benefits for lost pay, none of their benefits being affected. Second, a temporary leave of some employees, which means that employers have the intention to rehire them down the road, the employees being typically able to collect unemployment benefits while on an unpaid layoff, and frequently employers will allow employees to maintain benefits coverage for a defined period of time as an incentive to remain available for recall. Third, permanent layoff, with no anticipated rehire date being associated with it, and the relationship with the employee being also terminated.

In our research, managers were asked if they dismissed or intended to dismiss employees due to the crisis caused by COVID-19. They were also asked if the demand for their products/services had been affected by this crisis. Taking into consideration the whole cycle leading to unemployment and all information mentioned above, the fourth hypothesis has been formulated:

Hypothesis 4. There is a positive correlation between the act of dismissing employees/the intention to dismiss employees due to the crisis caused by COVID-19 and the fact that customers of companies were affected and the demand was lower than under normal conditions.

During the pandemic, managers have been facing challenges related to labour force, consumer demand, and risk anticipation $[41,59]$. In some areas, the demand for services or products has grown excessively (for example, the demand for disinfecting products, face masks, or hospital services), while in others, it has dramatically fallen (good examples for this category are: The automotive industry; car manufacturing; air travels and cruises) [34,52,60,61]. In Canada, it is expected that the demand for premium food and other niche products will fall [62]. The declining demand and the lockdown enforcements have generated change and restructuring of work in all affected industries [34]. Thus, due to shrinking demand for services, retailing, tourism, aviation, and leisure, unemployment has been on the agenda of mainly services-dependent economies [34]. To provide support to their economies, governments should be involved in growing the demand for products and services [34]. As for high demand for hospital services, personnel with adequate skills and knowledge should be attracted, and it can be achieved by using organizational rewards [61,63].

ILO has three scenarios for global unemployment generated by the COVID-19 crisis: A rise in unemployment reaching 5.3 million people, second, a rise amounting to 24.7 million, and lastly, 
13 million people [1]. In comparison, the rise in real unemployment during the economic crisis of 2008-2009 reached 22 million people [1]. Labour reductions and work in the informal sector are expected to appear, especially in SMEs [64].

Furloughed workers are staff who are no longer able to go to work, or work less hours because their places of employment have been forced to close or have a reduced operation due to the pandemic [65]. The term used for these temporary lay-offs or reduced working hours is different from one country to another, so we have encountered such terms as "temporary unemployment" (France) [66], "technical unemployment" (Romania) [21], "short-work" (Germany) [67], "reduced working time" (Suisse) [68], "temporary leave" (Spain) [66]. The employers saw this as a fair treatment of their employees, considering the exceptional context, and behaved in solidarity with their employees. In the UK, a report made public in May 2020, stated that across all industries, $28.0 \%$ of the workforce had been furloughed [69]. In August 2020, most employees returning to work from furloughing were in retailing, constructions, hotel industry, wholesale, and restaurants [49].

The solution of suspending employment contracts through furlough (or any other equivalent name which is used in other countries) is a temporary measure for employers wishing to cope with the economic crisis generated by COVID-19. The term furlough does not have the same meaning as unemployment, but both concepts stand for measures that appeared during the COVID-19 pandemic due to liquidity blockages.

There is no doubt that insufficient liquidity can lead to closure of businesses [39]. Thus, in the areas where COVID-19 was spread, the member states of the European Union (EU) were requested to take special measures for supporting firms and employees [45,70]. Further, countries like Spain, Italy, France, Swiss, Germany, and UK have been examples of applying different COVID-19 Job Retention Schemes (CJRS) and financial help for individuals and companies as well [66-69,71,72].

According to the previous analysis, there is no doubt that customer demand has decreased dramatically during this period, and that, implicitly, the level of cash flow in companies has gone down. Thus, in our research, managers were asked to tick the percentage of suspended employment contracts through temporary leave (furlough) due to the COVID crisis. They were also asked to disclose whether cash flow for maintaining the company's staff and activities is insufficient. So, the following hypothesis has been formulated:

Hypothesis 5. There is a positive correlation between the percentage of suspended employment contracts through temporary leave/furloughing and the fact that the cash flow for maintaining the company's staff and activities is insufficient.

The crisis has already transformed into an economic and labour market shock, impacting not only supply (production of goods and services), but also the demand (consumption and investments) [8]. The pandemic and lockdown will curtail current and near-term aggregate demand through several channels: Temporary shutdown or reduction of epidemic risky activities; temporary disruptions of supply in economy; high economic uncertainty depresses consumption expenditure and investment demand [73]. Due to these prospects, forecasts for companies in what regards their workforce needs had been and will continue to be negative, leading to dismissals or to temporary leaves (furloughs). Taking into consideration all the above-mentioned arguments, including those used for formulating hypothesis $\mathrm{H} 5$, the following hypothesis has been formulated:

Hypothesis 6. There is a positive correlation between the percentage of suspended employment contracts through temporary leavelfurloughing and the fact that company customers have been affected and the demand has been lower than under normal conditions. 


\section{Methodology and Data}

This study was conducted using a questionnaire translated and adapted from the ILO [3]. The purpose of the ILO research was to assess the needs of companies during the COVID-19 crisis. The purpose of our research is to point out what were the main challenges faced by Romanian companies due to the crisis generated by COVID-19, with a focus on the relations between low demand, cash flow problems, the dismissals, and employee temporary leaves. The study seeks to answer the following research question: What are the relations between low demand, cash flow problems, dismissals, and temporary leaves of employees generated by the lockdown imposed by the Romanian Government during the first two months of the COVID-19 pandemic? Data were collected online between 1-16 May 2020 in Romania from decision-makers in companies (owners, directors, administrators, or branch managers), ensuring the confidentiality of responses.

A total of 203 responses were collected: 96 (47.29\%) through the Chamber of Commerce and Industry of Iasi (CCI), a direct official e-mail was sent to companies, and 107 (52.71\%) through messages sent by members of the research team directly to company managers (on LinkedIn, e-mail, and social networks). A total of 180 e-mails sent by our team produced a response rate of $59.44 \%$, and a total of 900 having been contacted by e-mail generated a response rate of $10.66 \%$. Even if the two collection channels were different, the same questionnaire was used, the status of decision-makers having been constantly monitored, ensuring the quality of responses.

As part of the agreement with the Chamber of Commerce and Industry of Iasi, early results of this data collection were presented in May 2020 in a non-scientific public report made for the Romanian business community [74]. For this article, we complied with the ethics of publication by making sure that the title, the literature review, processed data, interpretations, and conclusions in this article are original, therefore not found in conflict with the content of the earlier presented public report.

Table 1 shows the registered offices of companies by county, for which the respondents provided information.

Table 1. Registered offices of companies by county.

\begin{tabular}{ccc}
\hline County & Frequency & Percentage (\%) \\
\hline Botoșani & 29 & 14.29 \\
Brașov & 1 & 0.49 \\
Buzău & 1 & 0.49 \\
Cluj & 3 & 1.48 \\
Dâmbovița & 13 & 6.40 \\
Galați & 1 & 0.49 \\
Harghita & 1 & 0.49 \\
Ialomița & 1 & 0.49 \\
Iași & 119 & 58.64 \\
Ilfov & 12 & 5.91 \\
Neamt & 5 & 2.46 \\
Sibiu & 1 & 0.49 \\
Suceava & 11 & 5.42 \\
Teleorman & 5 & 2.46 \\
Total & $\mathbf{2 0 3}$ & $\mathbf{1 0 0}$ \\
\hline
\end{tabular}

Source: Data processed using the output of SPSS version 21.0.

Data were collected in companies based in Iași (119 answers, 58.64\%), Botoșani (29, 14.29\%), Dâmbovița (13 answers, $6.40 \%$ ), and Ilfov (12 answers, 5.91\%). Respondents were also asked to specify the sectors in which their companies operate. Data are presented in Table 2.

As shown by the collected data, the IT industry is the leading sector in which companies operate (49 companies, $18.22 \%$ of total sectors). Trade and sales hold the second position ( 39 companies, $14.50 \%$ of total companies). Next is education (16 companies, $5.95 \%$ of the total sectors). Other types of business specified by respondents mainly as a second option covered healthcare system, 
the pharmaceutical industry, business consulting, advertising services, event organization, engineering, as well as manufacturing and services.

Table 2. Company operations by sector.

\begin{tabular}{ccc}
\hline Sector(s) of Operation & Frequency & Percentage (\%) \\
\hline Financial activities and insurance & 5 & 1.86 \\
Real estate & 7 & 2.60 \\
Agriculture/farm/fishing & 8 & 2.97 \\
Chemicals and plastics & 1 & 0.37 \\
Commerce/Sales & 39 & 14.50 \\
Construction & 12 & 4.46 \\
Electronic and electrical equipment & 12 & 4.46 \\
Education & 16 & 5.95 \\
Manufacture of metals and machinery & 4 & 1.49 \\
Hotels/Tourism & 8 & 2.97 \\
Food and beverage industry & 5 & 1.86 \\
Information and communication & 6 & 2.23 \\
IT & 49 & 18.22 \\
Food services (Restaurants) & 15 & 5.58 \\
Forestry/Wood/Paper products & 1 & 0.37 \\
Textiles, leather and clothing & 13 & 4.83 \\
Transport and transport of equipment & 7 & 2.60 \\
Other areas & 61 & 22.68 \\
Total & $\mathbf{2 6 9}$ & $\mathbf{1 0 0}$ \\
\hline
\end{tabular}

Source: Data processed using the output from SPSS version 21.0.

The total number of sectors covered by company operations (269, details shown in Table 2 ) is greater than the number of companies included in our research (203, details shown in Table 1$)$ as some companies have more than two types of activities in their portfolio.

The respondents also indicated the total number of employees of their company before the establishment of the state of emergency in Romania, generated by COVID-19-45.32\% of companies have between 1 and 10 employees; 37.44\% between 11 and 100 employees; 7.39\% between 101 and 250 employees, and $9.85 \%$ have more than 251 employees (or even 251).

The variables used in this study have been adapted after ILO [3]. The used questions and the scales will be presented in the results section.

Cronbach Alpha coefficient for checking the internal consistency of the used questionnaire was calculated strictly for the 14 items of the study. Its value is 0.620 (greater than 0.600 ), therefore it has been confirmed that the internal consistency of the items used in the analysis of results is acceptable. However, it could be questioned as the number of responses $(N=203$, see details in Table 1$)$ is limited due to the fact that responses were collected only during the state of emergency in Romania.

To start the research investigating the challenges Romanian companies have to face due to the crisis generated by COVID-19, their condition should first be described. Figure 1 shows the extent to which employees working in companies included in the study work from home or at the company's headquarters.

In the analysed period, only a small percentage of companies stopped operations (29.06\%), while most companies decided to move online or work remotely, or both (see details in Figure 1 and Table 3).

The frequency analyses show that $80.30 \%$ of the responding companies mentioned neither dismissing, nor planning to dismiss workers due to the crisis generated by COVID-19. Moreover, almost half of the companies within our sample had no employees on temporary leave (furlough). 


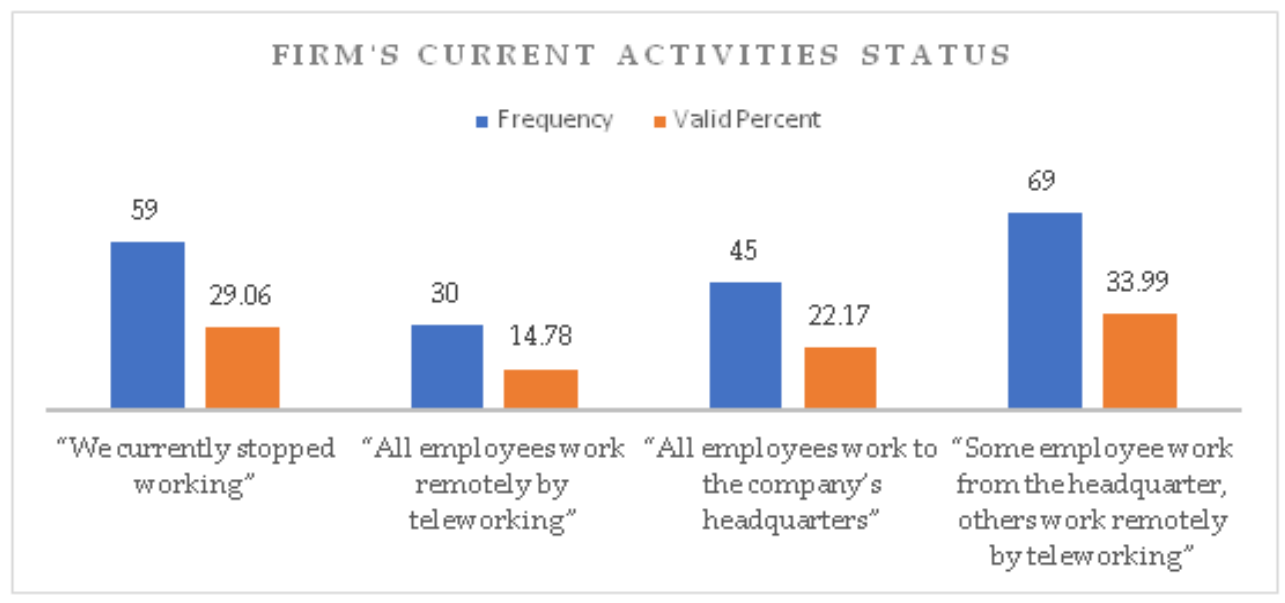

Figure 1. Status of current activities.

For the analysed sample, between 16 March and 16 May 2020, 96.55\% of respondents stated that there had been no cases of employees infected with COVID-19 in their companies, or in their families (94.09\%). However, almost half of our sample considers that COVID-19 crisis will strongly affect their business, and the financial impact will be high. More specifically, $51.22 \%$ of the respondents reported that the average monthly revenue decreased by more than $40 \%$, and $62.07 \%$ of respondents stated that the cash flow for maintaining staff and company's actions had been a major challenge. Out of surveyed companies, only $33.50 \%$ of the employed staff were absent from work (for medical reasons or due to governmental restrictions), while the procurement of raw materials needed for production had not been a major challenge for $59.61 \%$ of respondents. Most respondents believed that suppliers had been able to send inputs $(67.98 \%)$, only $32.02 \%$ stating that it had been impossible for suppliers to do so (details in Table 3).

Additionally, $66.50 \%$ of respondents considered that their business partners had been severely affected and failed to operate under normal conditions, while only $33.50 \%$ denied it. Moreover, most respondents believed that buyers/customers had been affected, the demand being lower than normal $(80.79 \%$ ), while only $19.21 \%$ saw no decrease in demand under current conditions (see details in Table 3). 
Table 3. Frequency distribution in our sample $(\mathrm{N}=203)$.

\begin{tabular}{|c|c|c|c|c|}
\hline Questions/Codes & Items & Frequency & $\begin{array}{c}\text { Valid } \\
\text { Percent }\end{array}$ & $\begin{array}{c}\text { Cumulative } \\
\text { Percent }\end{array}$ \\
\hline \multirow{4}{*}{ How is your company currently operating? (FIRMACT) } & “We currently stopped working" & 59 & 29.06 & 29.06 \\
\hline & "All employees work remotely by teleworking" & 30 & 14.78 & 43.84 \\
\hline & "All employees work at the company's headquarters" & 45 & 22.17 & 66.01 \\
\hline & $\begin{array}{l}\text { "Some employees work from the headquarter, others } \\
\text { work remotely by teleworking" }\end{array}$ & 69 & 33.99 & 100.00 \\
\hline \multirow{4}{*}{$\begin{array}{l}\text { Have you dismissed or do you plan to dismiss any workers due to } \\
\text { COVID-19? (DISMISSW) }\end{array}$} & “No" & 163 & 80.30 & 80.30 \\
\hline & "Yes" & 40 & 19.70 & 100.00 \\
\hline & "We did not fire employees" & 166 & 81.77 & 81.77 \\
\hline & “1-10\%" & 18 & 8.87 & 90.64 \\
\hline \multirow{4}{*}{$\begin{array}{l}\text { What is the percentage of dismissed workers? Check the percentage } \\
\text { of workers laid off compared to your total workforce. (RELEASEDW) }\end{array}$} & $" 11-20 \% "$ & 4 & 1.97 & 92.61 \\
\hline & $" 21-30 \% "$ & 5 & 2.46 & 95.07 \\
\hline & "31-40\%" & 4 & 1.97 & 97.04 \\
\hline & "Over $41 \% "$ & 6 & 2.96 & 100.00 \\
\hline \multirow{6}{*}{$\begin{array}{l}\text { Have you suspended employment contracts due to temporary leave } \\
\text { (furlough)? If so, what is the percentage of employees sent to } \\
\text { temporary leave (furlough) compared to the total workforce? } \\
\text { (SUSCONTRACTS) }\end{array}$} & $\begin{array}{c}\text { "We did not have employees on temporary leave } \\
\text { (furlough)" }\end{array}$ & 98 & 48.27 & 48.27 \\
\hline & "1-10\%" & 9 & 4.43 & 52.70 \\
\hline & $" 11-20 \% "$ & 10 & 4.93 & 57.63 \\
\hline & $" 21-30 \% "$ & 4 & 1.97 & 59.60 \\
\hline & "31-40\%" & 10 & 4.93 & 64.53 \\
\hline & "Over $41 \% "$ & 72 & 35.47 & 100.00 \\
\hline Do you have cases of employees infected with COVID-19? & "No" & 196 & 96.55 & 96.55 \\
\hline (INFECTEDEMPLY) & "Yes" & 7 & 3.45 & 100.00 \\
\hline \multirow{3}{*}{$\begin{array}{l}\text { Do you have cases of family members of employees infected with } \\
\text { COVID-19? (INFECTEDFAM) }\end{array}$} & "No" & 191 & 94.09 & 94.09 \\
\hline & "Yes" & 12 & 5.91 & 100.00 \\
\hline & "Not applicable" & 24 & 11.82 & 11.82 \\
\hline \multirow{3}{*}{$\begin{array}{l}\text { What was the level of financial impact (revenue or sales) on your } \\
\text { business and on the company's operations? (FINIMPACT) }\end{array}$} & "Low" & 34 & 16.75 & 28.57 \\
\hline & "Medium" & 55 & 27.09 & 55.66 \\
\hline & "High" & 90 & 44.34 & 100.00 \\
\hline \multirow{6}{*}{$\begin{array}{l}\text { How much did the company's average monthly revenues decreased } \\
\text { since the state of emergency has been established? (DIMINCOME) }\end{array}$} & "Not applicable" & 41 & 20.20 & 20.20 \\
\hline & "10-20\%" & 18 & 8.87 & 29.07 \\
\hline & $" 21-30 \% "$ & 25 & 12.32 & 41.39 \\
\hline & "31-40\%" & 15 & 7.39 & 48.78 \\
\hline & "41-50\%" & 13 & 6.40 & 55.18 \\
\hline & "51\% and over" & 91 & 44.82 & 100.00 \\
\hline
\end{tabular}


Table 3. Cont

\begin{tabular}{|c|c|c|c|c|}
\hline Questions/Codes & Items & Frequency & $\begin{array}{l}\text { Valid } \\
\text { Percent }\end{array}$ & $\begin{array}{c}\text { Cumulative } \\
\text { Percent }\end{array}$ \\
\hline \multicolumn{5}{|c|}{ Which are the main challenges your company is currently facing resulting from COVID-19? } \\
\hline Cash flow for maintaining staff and the company's actions is & "No" & 77 & 37.93 & 37.93 \\
\hline insufficient (LOWCASHFLOW) & "Yes" & 126 & 62.07 & 100.00 \\
\hline Workers are absent from work due to illness or governmental orders & "No" & 135 & 66.50 & 66.50 \\
\hline$($ ABSENTEEISM $)$ & "Yes" & 68 & 33.50 & 100.00 \\
\hline Raw materials are not in stock or their purchase has become very & "No" & 121 & 59.61 & 59.61 \\
\hline expensive (LACKROWMAT) & "Yes" & 82 & 40.39 & 100.00 \\
\hline \multirow{2}{*}{ Suppliers cannot send us inputs (LACKINPUTS) } & "No" & 138 & 67.98 & 67.98 \\
\hline & "Yes" & 65 & 32.02 & 100.00 \\
\hline Business partners have been severely affected and are not operating & "No" & 68 & 33.50 & 33.50 \\
\hline under normal conditions (AFFECTEDBUSS) & "Yes" & 135 & 66.50 & 100.00 \\
\hline Buyer/customers have been affected and demand is lower than & $" \mathrm{No}^{\prime \prime}$ & 39 & 19.21 & 19.21 \\
\hline normal (AFFECTEDBUYERS) & "Yes" & 164 & 80.79 & 100.00 \\
\hline
\end{tabular}

Source: Questions and items adapted after ILO (International Labour Organization. Assessing the needs of enterprises resulting from COVID-19, 2020). Data processed using the output from SPSS version 21.0. 


\section{Results}

In our study, we have used the Pearson correlation coefficient to test the hypotheses. Next, we will be presenting the results of the correlation analysis.

For the H1 hypothesis, there is a positive correlation between the act of dismissing employees/the intention to dismiss employees due to the crisis caused by COVID-19 (variable DISMISSW) and the percentage of dismissed employees (calculated as a percentage of total workforce) (variable RELEASEDW).

The Pearson correlation coefficient was calculated to measure both the strength and direction of the correlation between the act of dismissing employees/the intention to dismiss employees due to the crisis caused by COVID-19 and the actual percentage of dismissed employees (calculated as a percentage of the total workforce). Results show that there is a positive and strong correlation between the variables, with a correlation coefficient of 0.749 . The associated $p$ value (lower than 0.05 ) shows a significant correlation between the analysed variables (correlation is significant at the 0.01 level; 2-tailed). Therefore, the hypothesis $\mathrm{H} 1$ has been validated. In other words, the hypothesis indicates that there is a strong link between the past action of dismissal of employees (if applicable) and the percentage of actually dismissed (declared) employees. This indicates that the respondents were in good faith and honestly answered the two questions, which is quite important for our analysis.

When testing the $\mathrm{H} 2$ hypothesis, results showed that there is a positive correlation between the dismissal of employees/the intention to dismiss employees due to the crisis generated by COVID-19 (variable DISMISSW) and the fact that the cash flow for maintaining staff and company's actions is insufficient (variable LOWCASHFLOW).

As shown by the Pearson correlation coefficient of 0.285 , there is a weak correlation between the dismissal of employees/the intention to dismiss employees due to the crisis generated by COVID-19 and the fact that the cash flow for maintaining staff and the company's actions is insufficient. Therefore, hypothesis $\mathrm{H} 2$ has been validated. Given that the decision to lay off employees is not very widespread $(19.70 \%$ of respondent companies decided to lay off some of their employees, and $80.30 \%$ had no layoffs, having no intention to lay off employees due to the crisis caused by COVID-19, see details in Table 3), it explains the weak correlation between the two variables. The correlation between the two variables is significant ( $p$ value is equal to 0.01 , lower than 0.05 -correlation is significant at the 0.01 level; 2-tailed).

For the $\mathrm{H} 3$ hypothesis, there is a positive correlation between the percentage of employees laid off due to the crisis generated by COVID-19 (RELEASEDW) and the fact that the cash flow for maintaining staff and the company's actions is insufficient (LOWCASHFLOW).

Pearson correlation coefficient (0.217) indicates that there is a weak and positive correlation between the percentage of employees laid off due to the crisis generated by COVID-19 and the fact that the cash flow for maintaining staff and the company's actions is insufficient. The $p$ associated value is lower than 0.05 ( $p$ value equal to $0.01 ; 2$-tailed), which shows a significant correlation between the analysed variables, therefore hypothesis $\mathrm{H} 3$ has been validated. Given that $81.77 \%$ of the companies included in the study had no layoffs (details in Table 3), the weak correlation between the two variables is explained.

The results of testing the $\mathrm{H} 4$ hypothesis showed that there is a positive correlation between the dismissal of employees/the intention to dismiss employees due to the crisis generated by COVID-19 (DISMISSW) and the fact that the customers of the companies were affected and the demand is lower than under normal conditions (AFFECTEDBUYERS).

The dismissal of employees/the intention to dismiss employees due to the crisis generated by COVID-19 is positively and weakly correlated, with a correlation coefficient of 0.179 , with the fact that the buyers/customers of the companies were affected and the demand is lower than under normal conditions. The $p$ associated value lower than 0.05 shows a significant correlation between the analysed variables, therefore hypothesis $\mathrm{H} 4$ has been validated ( $p$ value equal to 0.01 ; 2-tailed). 
When testing the H5 hypothesis, the results showed that there is a positive correlation between the percentage of suspended employment contracts through temporary leave/furloughing (SUSCONTRACTS) and the fact that the cash flow for maintaining the company's staff and activities is insufficient (LOWCASHFLOW).

The percentage of suspended employment contracts due to temporary leave (furlough) is positively correlated with the fact that the cash flow for maintaining the company's staff and actions is insufficient, with a correlation coefficient of 0.357 and a significance level of 0.01 ( $p$ value lower than 0.05 ; 2-tailed), therefore hypothesis $\mathrm{H} 5$ has been validated.

The results of testing the H6 hypothesis showed that there is a positive correlation between the percentage of suspended employment contracts through temporary leave/furloughing (SUSCONTRACTS) and the fact that the customers of the companies were affected and the demand is lower than under normal conditions (AFFECTEDBUYERS).

There is a positive correlation between the percentage of suspended employment contracts due to temporary leave (furlough) and the fact that the buyers/customers of companies were affected, and the demand is lower than under normal conditions, with a Pearson correlation coefficient of 0.312 . The $p$ value lower than 0.05 ( $p$-value is equal to $0.01 ; 2$-tailed) displays a significant correlation between the analysed variables, therefore hypothesis $\mathrm{H} 6$ has been validated. When the demand for the products or services offered by the company is lower than normal, it is natural that the company's revenues decrease, and, implicitly, it no longer has the same financial power to support the company's salaries and/or activities, which involves a certain financial turnover. Thus, the short-term solution is temporary leave (furlough) for some of the employees (if not for all). However, a very important observation for this aspect is that, not in all countries, temporary leave (furlough) can be granted as the system of contributions withheld from the gross salary differs.

An additional correlation that can be analysed, besides the established hypotheses, is between the percentage of dismissed employees (calculated as a percentage of total workforce) (variable RELEASEDW) and the percentage of suspended employment contracts through temporary leave/furloughing (SUSCONTRACTS). There is a positive correlation between these two variables. The Pearson correlation coefficient is 0.303 , with a $p$ value of 0.01 (2-tailed), which is less than 0.05 , thus the correlation is significant. Normally, there should be a negative correlation between temporary leave/furloughing and dismissals. However, from the descriptive analysis (details in Table 3), it can be observed that both temporary leave/furloughing and dismissals were present in different proportions. The correlation is weak (though positive), therefore it strengthens the result, according to which employers had to use both measures.

The "backward" method was chosen for the multiple linear regression, which initiates the model by including all predictors in its composition. After removing the first insignificant variable, the model is adjusted. This last procedure is performed until the optimal model is obtained.

For the multiple regression the estimation framework is based on the following model:

$$
\begin{gathered}
\text { DIMINCOME }=\beta 0+\beta 1 \text { LOWCASHFLOW }+\beta 2 \text { ABSENTEEISM }+\beta 3 \\
\text { LACKINPUTS }+\beta 4 \text { AFFECTEDBUYERS }+\xi
\end{gathered}
$$

where:

DIMINCOME—a dependent variable which indicates how much the company's average monthly revenues decreased since the state of emergency had been established;

LOWCASHFLOW - an independent variable that shows the cash flow to maintain staff and business operations is insufficient; the variable is dichotomous, with the value coded by " 1 " for an affirmative answer, and " 0 " otherwise;

ABSENTEEISM —an independent variable that indicates that workers are absent from work due to illness or governmental orders; the variable is dichotomous, with the value coded by " 1 " for an affirmative answer, and "0" otherwise; 
LACKINPUTS-an independent variable that shows the lack of inputs provided by suppliers, coded by " 1 " for an affirmative answer, and " 0 " otherwise;

AFFECTEDBUYERS - an independent variable that shows that buyers/customers have been affected and demand is lower than normal; the variable is dichotomous, with the value coded by " 1 " for an affirmative answer, and " 0 " otherwise.

The results obtained for estimating the regression model are shown in Table 4.

Table 4. Ordinary least squares (OLS) regression model.

\begin{tabular}{|c|c|c|c|c|c|c|}
\hline \multicolumn{2}{|c|}{ Model OLS regression } & \multicolumn{2}{|c|}{$\begin{array}{l}\text { Unstandardized } \\
\text { Coefficients }\end{array}$} & \multirow{2}{*}{$\begin{array}{c}\begin{array}{l}\text { Standardized } \\
\text { Coefficients }\end{array} \\
\text { Beta }\end{array}$} & \multirow[t]{2}{*}{$\mathbf{t}$} & \multirow[t]{2}{*}{$p$} \\
\hline & & B & Std. Error & & & \\
\hline \multirow{5}{*}{ Model 1} & (Constant) & 1.729 & 0.434 & & 3.984 & 0.000 \\
\hline & LOWCASHFLOW & 0.906 & 0.239 & 0.273 & 3.795 & 0.000 \\
\hline & ABSENTEEISM & 0.815 & 0.219 & 0.267 & 3.718 & 0.000 \\
\hline & LACKINPUTS & 0.169 & 0.229 & 0.053 & 0.738 & 0.462 \\
\hline & AFFECTEDBUYERS & 1.151 & 0.410 & 0.201 & 2.807 & 0.006 \\
\hline \multirow{4}{*}{ Model 2} & (Constant) & 1.796 & 0.424 & & 4.236 & 0.000 \\
\hline & LOWCASHFLOW & 0.923 & 0.237 & 0.278 & 3.889 & 0.000 \\
\hline & ABSENTEEISM & 0.832 & 0.218 & 0.272 & 3.818 & 0.000 \\
\hline & AFFECTEDBUYERS & 1.120 & 0.407 & 0.196 & 2.750 & 0.007 \\
\hline
\end{tabular}

Dependent Variable: DIMINCOME. Source: Data processed using the output from SPSS version 21.0.

In this model, both $\mathrm{R}^{2}$ and adjusted $\mathrm{R}^{2}$ have values greater than 0.4 , indicating medium to large proportions of the variation of the average monthly revenues of the companies since the installation of the state of emergency, which is explained by the regression model.

Analysis of the regression coefficients shows that the values of $t$ test are all either less than -2 or greater than +2 , indicating that the considered variables are appropriate for the estimated model. In model 2, the $p$ values associated with the regression coefficients are less than or equal to the significance threshold of $\alpha=0.05$ for the explanatory variables which means that the three estimated coefficients are significant for the companies from which the sample was extracted.

The level of decrease of the average monthly revenue of companies since the establishment of the state of emergency was positively affected by all independent variables included in the model 2. In other words, the decrease of the average revenue of the companies since the establishment of the state of emergency is even greater, as the cash flow to maintain staff and business operations is insufficient, workers are absent from work due to illness or government orders, buyers/customers having been affected and demand is lower than normal, respectively.

For the model 2, we applied different tests for validation: Multicollinearity between independent variables among others.

Tolerance levels for all explanatory variables in the chosen model (the second model) are not close to $0(0.983 ; 0.986 ; 0.989)$ and the Variance inflation factor VIF indicator for the same variables $(1.018$; $1.014 ; 1.011$ ) has values close to 1 (and not values over 5 or even 10), which leads us to the exclusion of the existence of multicollinearity of the independent variables in the model (details in Table 5). 
Table 5. Model 2-Collinearity statistics.

\begin{tabular}{ccc}
\hline \multirow{2}{*}{ Model 2-OLS Regression } & \multicolumn{2}{c}{ Collinearity Statistics } \\
\cline { 2 - 3 } & Tolerance & VIF \\
\hline (Constant) & & \\
LOWCASHFLOW & 0.983 & 1.018 \\
ABSENTEEISM & 0.986 & 1.014 \\
AFFECTEDBUYERS & 0.989 & 1.011 \\
\hline
\end{tabular}

Dependent Variable: DIMINCOME. Source: data processed using the output from SPSS version 21.0.

The normality of the regression model's residuals was tested, and the results indicate normal distribution of the data.

Table 6 illustrates the residual indicators values for our model.

Table 6. Model 2-Residuals statistics.

\begin{tabular}{ccccc}
\hline Residuals Statistics & Minimum & Maximum & Mean & Std. Deviation \\
\hline Predicted Value & 1.80 & 4.67 & 3.83 & 0.684 \\
Residual & -2.838 & 2.372 & 0.000 & 1.337 \\
Std. Predicted Value & -2.970 & 1.233 & 0.000 & 1.000 \\
Std. Residual & -2.103 & 1.758 & 0.000 & 0.991 \\
\hline
\end{tabular}

Dependent Variable: DIMINCOME.

As it can be seen, the mean of the errors for model 2 is equal to 0 (details in Table 6). Thus, it has been confirmed that the model is suitable for the considered variables.

\section{Discussion}

The aim of our study was to discover the main challenges that Romanian companies were confronted with during the economic lockdown during the first two months of the COVID-19 pandemic outbreak in Romania (16 March-16 May 2020). The focus has been on the relations between low demand, cash flow problems, dismissals, and temporary leaves of employees.

The most important feature of this study is that data were collected from company decision-makers (managers, shareholders, company owners, administrators, etc.) during the last two weeks of the state of emergency in Romania (1 May through 16 May 2020), established due to the COVID-19 epidemic, the period with the maximum economic and personal movement restrictions.

The second important feature of this study is that the results could be compared at a later time to other internationally available data, collected using the same ILO questionnaire.

All the hypotheses of the study have been validated, showing positive correlations, although specific explanations should be given for the strengths of resulted correlations.

The first hypothesis was formulated to test the good faith of respondents. We obtained a correlation coefficient of 0.749 , hence a strong and positive correlation between the past action of dismissal of employees and the percentage of current dismissed employees.

When we analysed the correlations between the cash flow problems and the reduction of the employee activity, through dismissals or temporary leaves, the level of the correlation coefficient was high enough to validate the hypotheses, but showing weak correlations. The same weak correlations appeared also when we analysed the relation between low demand and dismissals or temporary leaves.

When we designed the study, the general economic thinking led us to an expectation of a rational economic decision of employers to promptly react in order to preserve their financial interests, hence generating strong correlations with previously experienced situations.

In order to explain the weak correlations, we must consider some potential moderators which have not been considered in the design of this study, since their impact was indirectly acknowledged 
only after seeing our results. Some of the moderators of low demand, cash flow problems, percentage of dismissals, and temporary leaves are presented in the following arguments.

A first possible moderator is the percentage of employees transferred to working from home at the beginning of the crisis. A part of the reduced activity impact was attenuated by work from home, a situation in which the reduction of the degree of usage of the $8 \mathrm{~h}$ of work per day might become hidden or indistinguishable.

Another possible moderator is the governmental intervention offering several types of financial support for the companies: Delayed payment of taxes and fees, subsidies for the employees on temporary leaves, etc. Financial support from the government has a great potential of affecting the economic rationale of a company's situation. For example, unemployment insurance systems can include short-time compensation programs, and evidence exists that this kind of compensation programs reduce unemployment in downturns and also stabilize permanent employment [75].

A third possible moderator is the conservative approach of employers when deciding on dismissals or temporary leaves of employees, after years of acting in a scarce work market. As our study shows, $80.30 \%$ of companies had used a strategy of retaining employees during the crisis (see details in Table 3 ). Therefore, there is a propensity to keep the employees, even if this is not a perfectly sound economic decision, accepting short time losses in the hope of a potential return to the previous levels of business activity. Additionally, existing evidence seems to show that, usually, people who are reemployed have actually returned to the employers they had previously worked for, although, since job loss, the rate of reemployment decreases with time [76].

A fourth possible moderator is the volatility of informal employment. During crises, the tendency of informal employment is to increase [8]. We cannot exactly predict what happened with self-employed persons, with those already having a part-time job, or with those working on the black-market, but we can say that informal employment can reduce the strength of the correlation between a difficult economic situation of a company and staff reduction.

Finally, a fifth moderator can be the reallocation of jobs to other activities. This is less likely to have had an impact in our study, since only one month and a half passed since the beginning of the crisis, but, nevertheless, it should be considered. The COVID-19 pandemic is considered a major shock in terms of reallocation [73].

Besides the above mentioned and explained potential moderators, another possible explanation for the weak correlations that have resulted between the variables in the study can be determined based on the design of the study. First of all, the emergency situation had been in place only for one month and 15 days when we started collecting the data, hence, some economic figures were far from being clear for some managers. The situation was evolving so fast that many of them failed to understand the situation and react at all in due time to be able to solve the problems appearing in their companies. Second, the closure of our data collection at the same time with the end of the state of emergency imposed by the government has left us with a qualitative and small size sample. More precisely, even though our statistical methodology is accurate, the 203 responses might imply a rather low statistical strength.

\section{Limitations and Future Lines of Research}

The most important limitation comes from the fact that most companies, for which data were collected, are just from one county of Romania, the Iași county (119 answers, a percentage of $58.62 \%$ of the total number of respondents), which is the most developed county in the Eastern part of Romania. In order to ensure the best possible representativeness, the sample included all types of enterprises, considering their size and type of activity (at least, 18 different fields). The results cannot be generalised for all companies in Romania, even if the operational context of the companies included into the sample was perfectly identical with that of other companies in Romania.

Additionally, we believe that an analysis of specific fields of economic activity would be useful as to find out which fields of activity had been most affected, this could be further investigated in another 
study. In this study, this type of analysis was not possible, as time was short and data were collected during the state of emergency, which ensured that true information was collected in relation with challenges occurring during the pandemic. A future study could also explore the types of activities that maintain cash flow as much as possible and the strategies that kept the workforce inside companies during the COVID-19 pandemic.

Due to time constraints, we have encountered difficulties related to data collection, and no sampling scheme has been applied, therefore, the results cannot be generalized.

As this is an exploratory study and due to time constraints, another limitation lies in the fact that the relationships between the variables have been analysed only in terms of their correlations, without considering possible causal relationships. Hence, future research may consider similar studies, but of a longitudinal nature, which could lead to determining relationships of causal nature between the variables.

Our study suggested the potential presence of some moderators between low demand, cash flow problems, percentage of dismissals and temporary leaves, and therefore, future research can further investigate their real leverage in influencing the relations of these variables.

\section{Conclusions}

In Romania, the state of emergency brought many changes to the economic activity. According to the national legislative portals, the exercise of some free movement rights and some economic freedom rights were restricted [7], and a long list of economic activities were influenced by the newly imposed restrictions during the period between 16 March and 16 May 2020 [11-13].

The negative effects for the Romanian economy proved to be similar to other effects found in many other countries/regions: High cash flow decrease [18,22,30,33,38,39]; low demand for products/services [34,41,48,53,54,62], but not in all sectors [34,52,60,62]; dismissals [18,20,41,42], inconvenient wage cuts $[1,18,33,46]$, and temporary leaves/furloughing [65-69,72].

This is a predominantly quantitative study. It was conducted using a questionnaire translated and adapted from the ILO [3]. The purpose of our research was to point out what were the main challenges faced by Romanian companies due to the crisis generated by COVID-19 by focusing on the relations between low demand, cash flow problems, and dismissals and temporary leaves of employees. Data were collected online from decision-makers in companies (owners, directors, administrators, or branch managers), the confidentiality of responses being ensured. Data were collected in Romania between 1-16 May 2020. The results of the study have been analysed based on descriptive, correlation, and regression analyses.

According to the descriptive analysis, despite the fact that only a few cases of employee infections with COVID-19 had been reported by our respondents (3.45\% of respondents reported confirmed cases, see details in Table 3), and just a few cases of employee family members having been infected with this virus (5.91\%, see details in Table 3), the financial impact on companies proved to be quite serious: $44.34 \%$ of companies view financial impact as high (see details in Table 3), and the average monthly revenues for $44.82 \%$ of companies decreased by over $51 \%$ (see details in Table 3 ). At the same time, at the time of reporting, $29.06 \%$ of the companies stopped their activity (see details in Table 3).

On the one hand, most companies resorted to a strategy of retaining employees even during the crisis generated by COVID-19, so that $80.30 \%$ have not been dismissing employees and were not intending to dismiss employees (see details in Table 3). On the other hand, $48.27 \%$ of the analysed companies have not had any employees on a temporary leave (furlough), but $51.73 \%$ of the companies temporarily suspended the employment contracts of their employees, a condition called temporary leave (furlough) (see details in Table 3). As it is allowed by the Romanian legislation, a temporary leave (furlough) was a short-term solution counteracting the negative financial impact that companies had been facing at that time.

The main challenges currently faced by companies due to the crisis generated by COVID-19 are: Insufficient cash flow for maintaining any company's staff and size of activity $(62.07 \%$ of respondents 
reporting it); staff being absent from work due to medical reasons or governmental restrictions $(33.50 \%$ of respondents reporting it); business partners being severely affected and not operating under normal conditions ( $66.50 \%$ of respondents reporting it), and for $80.79 \%$ of companies, buyers/customers having been affected and the demand going lower than under normal conditions (see details in Table 3). On the other hand, the procurement of raw materials necessary for production had not been a challenge for $59.61 \%$ of the companies (see details in Table 3).

The six hypotheses considered in our research were tested using the correlation analysis. All of them have been validated, these results being representative only for the considered sample in the analysed period. Briefly, these confirm the following: There is a strong correlation between the past action of employee dismissals and the percentage of declared dismissed employees (H1); there is a weak correlation between the dismissal of employees/the intention to dismiss employees due to the crisis generated by COVID-19 and the fact that the company's cash flow is insufficient (H2), explained by the fact that only $19.70 \%$ of companies laid off or planned to dismiss workforce because of the economic crisis generated by COVID-19; there is a weak correlation between the percentage of employee layoffs due to the crisis generated by COVID-19 and the fact that the company's cash flow is not sufficient (H3), explained by the fact that only $81.77 \%$ of managers have not fired employees during this period (see details in Table 3); there is a weak correlation between the act of dismissing employees/the intention to dismiss employees due to the crisis caused by COVID-19 and the fact that the demand is lower than under normal conditions ( $\mathrm{H} 4)$; there is a correlation between the percentage of suspended employment contracts through temporary leave/furloughing and the fact that the company's cash flow is not sufficient (H5), showing that negative effects of this COVID-19 economic crisis can be counteracted by means of temporary leaves/furloughing; there is a correlation between the percentage of suspended employment contracts through temporary leave/furloughing and the fact that the demand is lower than under normal conditions (H6).

An additional correlation highlights the fact that, during COVID-19 crisis, employers dismissed employees and suspended employment contracts through temporary leave/furloughing simultaneously, even if these two measures seem to exclude each other.

The regression analysis shows that the average linear revenue of companies decreases as cash flow for maintaining personnel and company's actions becomes less sufficient, workers are more absent from work due to illness or governmental orders, buyers/customers becoming more affected, and demand getting lower than normal. We consider that this model could be improved in further research if more companies are included into the study and their differences are tested by sector.

Author Contributions: The authors' contributions were equal. Conceptualization, S.A.N., S.M.T., E.-S.T., A.I.V. and A.L.G.; methodology, S.A.N., S.M.T., E.-S.T., A.I.V., and A.L.G.; statistical method and analysis, E.-S.T., A.I.V., and A.L.G.; writing-original draft preparation S.A.N., S.M.T., and E.-S.T.; writing-review and editing, S.A.N., S.M.T., E.-S.T., A.I.V., and A.L.G. All authors have read and agreed to the published version of the manuscript.

Funding: This research received no external funding.

Conflicts of Interest: The authors declare no conflict of interest.

\section{References}

1. International Labour Organization. MSME Day 2020: The COVID-19 Pandemic and its Impact on Small Business. Available online: https://www.ilo.org/empent/whatsnew/WCMS_749275/lang--en/index.htm (accessed on 18 August 2020).

2. Popescu, C.R.G.; Popescu, G.N. An exploratory study based on a questionnaire concerning green and sustainable finance, corporate social responsibility, and performance: Evidence from the Romanian business environment. J. Risk Financ. Manag. 2019, 12, 162. [CrossRef]

3. International Labour Organization. Assessing the Needs of Enterprises Resulting from COVID-19. Available online: https://www.ilo.org/wcmsp5/groups/public/---ed_dialogue/---act_emp/documents/publication/ wcms_740215.pdf (accessed on 30 March 2020). 
4. World Health Organization. Origin of SARS-CoV-2. Available online: https://www.who.int/publications/i/ item/origin-of-sars-cov-2 (accessed on 20 August 2020).

5. World Health Organization. WHO Statement Regarding Cluster of Pneumonia Cases in Wuhan, China. Available online: https://www.who.int/china/news/detail/09-01-2020-who-statement-regarding-cluster-ofpneumonia-cases-in-wuhan-china (accessed on 20 August 2020).

6. World Health Organization. WHO Director-General's Opening Remarks at the Mission Briefing on COVID-19. Available online: https://www.who.int/dg/speeches/detail/who-director-general-s-opening-remarks-at-themission-briefing-on-covid-19---12-march-2020 (accessed on 20 August 2020).

7. Portal Legislativ. DECRET nr. 195 din 16 Martie 2020. Available online: http://legislatie.just.ro/Public/ DetaliiDocumentAfis/223831 (accessed on 20 August 2020).

8. International Labour Organization. ILO Monitor: COVID-19 and the World of Work. 1st Edition. Available online: https://www.ilo.org/global/about-the-ilo/WCMS_738753/lang--en/index.htm (accessed on 20 August 2020).

9. Centrul National de Supraveghere și Control al Bolilor Transmisibile. Analiza Rapida Cazurilor Confirmate de Infectie cu Coronavirus Covid 19. Available online: https:/www.cnscbt.ro/index.php/ analiza-cazuri-confirmate-covid19/1539-analiza-cazuri-confirmate-261-pana-la-18-03-2020/file (accessed on 20 August 2020).

10. Portal legislativ. DECRET nr. 240 din 14 aprilie 2020. Available online: http://legislatie.just.ro/Public/ DetaliiDocumentAfis/224849 (accessed on 20 August 2020).

11. Portal Legislativ. ORDONANȚ̆ MILITARĂ nr. 1 din 17 Martie 2020. Available online: http://legislatie.just. ro/Public/DetaliiDocument/223888 (accessed on 20 August 2020).

12. Portal Legislativ. ORDONANȚ̆ MILITARĂ nr. 2 din 21 martie 2020. Available online: http://legislatie.just. ro/Public/DetaliiDocument/224284 (accessed on 20 August 2020).

13. Portal Legislativ. ORDONANT, Ă MILITARĂ nr. 3 din 24 martie 2020. Available online: http://legislatie.just. ro/Public/DetaliiDocument/224340 (accessed on 20 August 2020).

14. Centrul Național de Supraveghere și Control al Bolilor Transmisibile. Covid 19 Raport Saptamanal de Supraveghere. Available online: https://www.cnscbt.ro/index.php/analiza-cazuri-confirmate-covid19/1742raport-saptamanal-episaptamana19/file (accessed on 20 August 2020).

15. Spurk, D.; Straub, C. Flexible employment relationships and careers in times of the COVID-19 pandemic. J. Vocat. Behav. 2020, 119, 103435. [CrossRef] [PubMed]

16. Bell, D.N.F.; Blanchflower, D.G. US AND UK LABOUR MARKETS BEFORE AND DURING THE COVID-19 CRASH. Natl. Inst. Econ. Rev. 2020, 252, R52-R69. [CrossRef]

17. Zhang, S.X.; Wang, Y.; Rauch, A.; Wei, F. Unprecedented disruption of lives and work: Health, distress and life satisfaction of working adults in China one month into the COVID-19 outbreak. Psychiatry Res. 2020, 288, 112958. [CrossRef] [PubMed]

18. Joshi, A.; Bhaskar, P.; Gupta, P.K. Indian Economy Amid COVID-19 Lockdown: A Prespective. J. Pure Appl. Microbiol. 2020, 14, 957-961. [CrossRef]

19. Donthu, N.; Gustafsson, A. Effects of COVID-19 on business and research. J. Bus. Res. 2020, 117, $284-289$. [CrossRef]

20. Account+or. Available online: https://www.accountor.com/en/ukraine/article/dismissing-employees-duringcovid-19-pandemic (accessed on 15 July 2020).

21. Romanian Labour Code. Available online: https://www.ilo.org/dyn/travail/docs/1630/ (accessed on 8 August 2020).

22. Açikgöz, Ö.; Günay, A. The early impact of the Covid-19 pandemic on the global and Turkish economy. Turk. J. Med. Sci. 2020, 50, 520-526. [CrossRef]

23. Tokic, D. Long-term consequences of the 2020 coronavirus pandemics: Historical global-macro context. J. Corp. Account. Financ. 2020, 31, 9-14. [CrossRef]

24. Denfeld, Q.; Erickson, E.; Valent, A.; Villasana, L.; Zhang, Z.; Myatt, L.; Guise, J.M. COVID-19: Challenges and Lessons Learned from Early Career Investigators. Women's Heal. 2020, 29, 752-754. [CrossRef]

25. VOXEU. Research-Based Policy Analysis and Commentary from Leading Economists. Available online: https://voxeu.org/article/labour-market-policy-response-covid-19-must-save-aggregate-matchingcapital (accessed on 17 August 2020). 
26. Hobbs, J.E. Food supply chains during the COVID-19 pandemic. Can. J. Agric. Econ. Can. D'agroeconomie 2020, 68, 171-176. [CrossRef]

27. Employment New Zealand. Available online: https://www.employment.govt.nz/leave-and-holidays/ other-types-of-leave/coronavirus-workplace/terminate-employment-agreement-covid-19/ (accessed on 15 July 2020).

28. Bratianu, C.; Vatamanescu, E.M.; Anagnoste, S.; Dominici, G. Untangling knowledge fields and knowledge dynamics within the decision-making process. Manag. Decis. 2020. [CrossRef]

29. Bratianu, C.; Neștian, A.Ș.; Tiță, S.M.; Vodă, A.I.; Guță, A.L. The Impact of Knowledge Risk on Sustainability of Firms. Amfiteatru Econ. 2020, 22, 639-652.

30. Ahmad, R.C.O.; Suraiya, I.; Mohd, A.J. The impact of Covid-19 Movement Control Order on SMEs' businesses and survival strategies. Malays. J. Soc. Space 2020, 16, 139-150.

31. Kawohl, W.; Nordt, C. COVID-19, unemployment, and suicide. Lancet Psychiatry 2020, 7, 389-390. [CrossRef]

32. Williams, C.C.; Kayaoglu, A. COVID-19 and undeclared work: Impacts and policy responses in Europe. Serv. Ind. J. 2020, 40, 914-931. [CrossRef]

33. VOXEU. Mitigating Mass Layoffs in the COVID-19 crisis: Austrian Short-Time Work as International Role Model. Available online: https://voxeu.org/article/mitigating-mass-layoffs-covid-19-crisis-austrian-shorttime-model (accessed on 17 August 2020).

34. Ceylan, R.F.; Ozkan, B.; Mulazimogullari, E. Historical evidence for economic effects of COVID-19. Eur. J. Heal. Econ. 2020, 21, 817-823. [CrossRef]

35. OECD. Record Rise in OECD Unemployment Rate in April 2020. Available online: www.oecd.org/sdd/ labour-stats/unemployment-rates-oecd-06-2020.pdf (accessed on 6 July 2020).

36. LSE. COVID-19 and Job Security: How to Prevent a 'Pandemic of Unemployment'. Available online: https://blogs.lse.ac.uk/politicsandpolicy/covid19-job-security/ (accessed on 17 August 2020).

37. U.S. Bureau of Labor Statistics. Available online: https://www.bls.gov/news.release/empsit.nr0.htm (accessed on 6 July 2020).

38. Ozili, P. COVID-19 in Africa: Socio-economic impact, policy response and opportunities. Int. J. Sociol. Soc. Policy 2020, 40. [CrossRef]

39. Hailu, G. Economic thoughts on COVID-19 for Canadian food processors. Can. J. Agric. Econ. Can. D'agroeconomie 2020, 68, 163-169. [CrossRef]

40. Said, M.; Hope, O.A. Coronavirus Pandemic in Nigeria: How can Small and Medium Enterprises (Smes) Cope and Flatten the Curve? Eur. J. Account. Financ. Investig. 2020, 6, 4242-4405.

41. Hakovirta, M.; Denuwara, N. How COVID-19 Redefines the Concept of Sustainability. Sustainability 2020, 12, 3727. [CrossRef]

42. Lexology. Available online: https://www.lexology.com/library/detail.aspx?g=c13af8da-ae17-4340-8462b5994bdc6224 (accessed on 15 July 2020).

43. Deloitte. COVID-19: Managing Cash Flow during a Period of Crisis. Available online: https://www2.deloitte.com/content/dam/Deloitte/global/Documents/About-Deloitte/gx-COVID-19managing-cash-flow-in-crisis.pdf (accessed on 15 July 2020).

44. Pietras, L.; Gross Mendelsohn. Layoff or Furlough: What's Right for Your Business? Available online: https://www.gma-cpa.com/blog/layoff-or-furlough-whats-right-for-your-business (accessed on 26 August 2020).

45. Goniewicz, K.; Khorram-Manesh, A.; Hertelendy, A.J.; Goniewicz, M.; Naylor, K.; Burkle, F.M., Jr. Current Response and Management Decisions of the European Union to the COVID-19 Outbreak: A Review. Sustainability 2020, 12, 3838. [CrossRef]

46. International Trade Centre (ITC). SME Competitiveness Outlook. COVID-19: The Great Lockdown and its Impact on Small Business; International Trade Centre (ITC): Geneva, Italy, 2020; pp. 1-154.

47. Forbes. Available online: https://www.forbes.com/sites/stevendennis/2020/04/21/covid-19-and-fashion-andluxury-retails-lost-season/\#347e6651707 (accessed on 8 August 2020).

48. Aloi, A.; Alonso, B.; Benavente, J.; Cordera, R.; Echániz, E.; González, F.; Ladisa, C.; Lezama-Romanelli, R.; López-Parra, Á.; Mazzei, V.; et al. Effects of the COVID-19 Lockdown on Urban Mobility: Empirical Evidence from the City of Santander (Spain). Sustainability 2020, 12, 3870. [CrossRef] 
49. Office for National Statistics. Labour Market Overview, UK: August, 2020. Available online: https://www.ons.gov.uk/employmentandlabourmarket/peopleinwork/employmentandemployeetypes/ bulletins/uklabourmarket/august2020\#employment-unemployment-and-economic-inactivity (accessed on 18 August 2020).

50. World Trade Organization. Available online: https://www.wto.org/english/news_e/news20_e/info_note_ covid_05aug20_e.pdf (accessed on 8 August 2020).

51. Wen, J.; Kozak, M.; Yang, S.; Liu, F. COVID-19: Potential effects on Chinese citizens' lifestyle and travel. Tour. Rev. 2020. [CrossRef]

52. Gössling, S.; Scott, D.; Hall, M. Pandemics, tourism and global change: A rapid assessment of COVID-19. J. Sustain. Tour. 2020, 1-20. [CrossRef]

53. Tufan, Z.K. COVID-19 Diaries of Higher Education during the Shocking Pandemic. Gazi Med. J. 2020, 31, 227-233. [CrossRef]

54. Gregorio, G.B.; Ancog, R.C. Assessing the Impact of the COVID-19 Pandemic on Agricultural Production in Southeast Asia: Toward Transformative Change in Agricultural Food Systems. Asian J. Agric. Dev. 2020, 17, 1-14. [CrossRef]

55. International Trade Centre. Available online: https://www.intracen.org/covid19/Blog/Quantifying-the-effectof-COVID-19-on-small-business-around-the-world-the-world/ (accessed on 8 August 2020).

56. Jagdish, S. Business of business is more than business: Managing during the COVID crisis. Ind. Mark. Manag. 2020, 88, 261-264.

57. Van Barneveld, K.; Quinlan, M.; Kriesler, P.; Junor, A.; Baum, F.; Chowdhury, A.; Junankar, P.N.R.; Clibborn, S.; Flanagan, F.; Wright, C.F.; et al. The COVID-19 pandemic: Lessons on building more equal and sustainable societies. Econ. Labour. Relat. Rev. 2020, 31, 133-157. [CrossRef]

58. Blustein, D.L.; Duffy, R.; Ferreira, J.A.; Cohen-Scali, V.; Cinamon, R.G.; Allan, B.A. Unemployment in the time of COVID-19: A research agenda. J. Vocat. Behav. 2020, 119, 103436. [CrossRef]

59. KPMG. COVID-19 and Tax Residency. Available online: https://home.kpmg/xx/en/blogs/home/posts/2020/ 04/covid-19-and-tax-residency.html (accessed on 18 August 2020).

60. Ivanov, D. Viable supply chainmodel: Integrating agility, resilience and sustainability perspectives-Lessons from and thinking beyond the COVID-19 pandemic. Ann. Oper. Res. 2020, 1-21. [CrossRef]

61. Raab, A.M.; Michel, F. Significant demands on healthcare resources during the COVID crisis. Spinal Cord 2020, 58, 728-729. [CrossRef]

62. Cranfield, J.A.L. Framing consumer food demand responses in a viral pandemic. Can. J. Agric. Econ. Can. D'agroeconomie 2020, 1-5. [CrossRef]

63. Turnea, E.S.; Prodan, A. The Relative Influence of Total Reward on Retention of Human Resources. Rev. de Cercet. si Interv. Soc. 2020, 69, 79-95. [CrossRef]

64. Zemtsov, S. New technologies, potential unemployment and 'nescience economy' during and after the 2020 economic crisis. Reg. Sci. Policy Pract. 2020, 12, 723-743. [CrossRef]

65. FTPA Avocats. Available online: https:/ftpa.com/en/new-rules-on-furlough-leave-is-your-company-eligibleto-french-state-aids/ (accessed on 18 August 2020).

66. Financial Times. France to Extend Crisis Jobs Scheme for up to Two Years. Available online: https: //www.ft.com/content/63b33ede-4463-4342-845a-26cf85a91d3d (accessed on 18 August 2020).

67. The Guardian. Germany to Extend Coronavirus Furlough to 24 Months. Available online: https://www. theguardian.com/world/2020/aug/18/germany-to-extend-coronavirus-furlough-to-24-months (accessed on 18 August 2020).

68. KPMG. Switzerland-Government Compensation for Employees Who Cannot Work Due to COVID-19. Available online: https:/home.kpmg/xx/en/home/insights/2020/03/flash-alert-2020-126.html (accessed on 18 August 2020).

69. Office for National Statistics. Labour Market Overview, UK: May, 2020. 2020. Available online: https://www.ons.gov.uk/employmentandlabourmarket/peopleinwork/employmentandemployeetypes/ bulletins/uklabourmarket/may2020\#employment (accessed on 18 August 2020).

70. Pacces, A.M.; Weimer, M. From Diversity to Coordination: A European Approach to COVID-19. Eur. J. Risk Regul. 2020, 11, 283-296. [CrossRef] 
71. Ius Laboris UK. Government to Pay Bonus for Retaining Furloughed Workers. Available online: https: //www.lewissilkin.com/en/insights/government-to-pay-bonus-for-retaining-furloughed-workers (accessed on 18 August 2020).

72. Ius Laboris UK. International Approaches to Covid-19 Job Retention and Wage Subsidy Schemes. Available online: https:/www.lewissilkin.com/en/insights/international-approaches-to-covid-19-job-retention-andwage-subsidy-schemes (accessed on 18 August 2020).

73. Barrero, J.M.; Bloom, N.; Davis, S.J. COVID-19 is also a Reallocation Shock; National Bureau of Economic Research: Cambridge, MA, USA, 2020; p. 27137. [CrossRef]

74. Camera de Comert și Industrie Lași. Impactul Epidemiei Covid-19 și al Măsurilor de Contracarare a Acesteia Asupra Firmelor. Available online: http://www.cciasi.ro/doc/Raport_cercetare_IMPACT_FIRME_COVID19_ UAIC_CCI_20052020.pdf?fbclid=IwAR39o13XKJWOHU51mzvW1-VB4aaCiXSgpcpLb7RJsYQyJ8gqedD8kP2nJw (accessed on 20 August 2020).

75. Cahuc, P.; Carcillo, S. Is Short-Time Work a Good Method to Keep Unemployment Down? Discussion Paper No. 5430 2011. Nordic Econ. Policy Rev. 2011, 1, 133-165.

76. Cheng, W.; Carlin, P.; Carroll, J.; Gupta, S.; Lozano Rojas, F.; Montenovo, L.; Nguyen, T.D.; Schmutte, I.M.; Scrivner, O.; Simon, K.I.; et al. Back to Business and (re)Employing Workers? Labor Market Activity during State Covid-19 Reopenings; Nber working paper series 2020; National Bureau of Economic Research: Cambridge, MA, USA, 2020.

Publisher's Note: MDPI stays neutral with regard to jurisdictional claims in published maps and institutional affiliations.

(C) 2020 by the authors. Licensee MDPI, Basel, Switzerland. This article is an open access article distributed under the terms and conditions of the Creative Commons Attribution (CC BY) license (http://creativecommons.org/licenses/by/4.0/). 